\title{
Congeminências atávicas: entre o desejo privado e a defesa pública
}

Antonio Alberto Brunetta'

OZ, Amós. Entre amigos. Tradução do hebraico e notas de Paulo Geiger. 1. ed. São Paulo: Companhia das Letras, 2014.

Tengo miedo de todo el mundo, del agua fría, de la muerte. Soy como todos los mortales, inaplazable.

A trama de acontecimentos narrados por Amós Oz em "Entre Amigos" (2014) encontra semelhança direta de forma com outro de seus romances, "Cenas da vida na aldeia" (2008), pois dispóe as personagens, em cada um dos capítulos-contos, ora como protagonistas, ora como figurantes dos dramas vividos individualmente, porém sempre comentados, debatidos e ridicularizados pelo coletivo. Cada um dos habitantes do kibutz Ikhat pratica e conforma sua idiossincrasia mutuamente, comentando, debatendo e ridicularizando a si mesmo.

Em contrapartida, o cotidiano racionalizado e assembleísta do kibutz, nos anos 1950, não é capaz de suprimir as expressōes sentimentais daqueles que nele habitam, muito embora sufoque as manifestaçóes explícitas de felicidade derivadas das sortes e conquistas individuais e privadas. O que resulta desse enfrentamento entre a satisfaçáo dos desejos - comuns a jovens, adultos e velhos - e a defesa das prioridades públicas é um cenário de utopias

Doutor em Ciências Sociais pela UNESP, Araraquara/SP. Professor do Departamento de Metodologia de Ensino (MEN), da Universidade Federal de Santa Catarina (UFSC), Florianópolis/SC. E-mail: aabrunetta@gmail.com. 
desencontradas, povoado por rostos sombrios, de sorrisos sarcásticos, alimentados de inveja crônica e solidão aguda.

A náusea comum da ontológica solidão embaça as relações sociais descritas no romance, configurando um conflito no qual estáo dispostos jovens tediosos, contra adultos angustiados, contra idosos moribundos, contra jovens angustiados... As soluçóes possíveis são impróprias, pois as novas e velhas geraçóes se esbarram, respectivamente, na eminência da tradição e na iminência do futuro.

Apesar de a organização coletiva do trabalho proporcionar o domínio do tempo, não há tempo de sobra; só resta aos habitantes de Ikhat esperar. Dessa forma, os capítulos encerram esperas que subjazem a materialidade do tempo: do cultivo à colheita, do flerte ao amor, da fecundação ao nascimento, do estudo ao aprendizado, do treinamento à guerra, do ensaio à apresentaçáo; embaralhando, em cada uma das personagens, em um único regime de necessidade, amalgamando - sem fazer convergirem - o pragmatismo do propósito sionista e o ideal epicurista, este explicitamente representado pelo trabalho do jardineiro Tzvi Provizor, personagem central do primeiro capítulo-conto que, embora tenha seu trabalho admirado por todos, criticamente afirma: "Fazer, nós podemos muito pouco. Então pelo menos é preciso dizer". Mas o que se pode dizer quando não existem interlocutores? Quando todos têm algo a dizer restam ouvintes? Ou ainda, uma língua universal resultará no silenciamento de todos?

Simultaneamente corajosos e prostrados, estáo todos à espera da morte que os ameaça de maneira comum, mas que os atingirá individualmente. Assim, os planos e as estratégias dessa polis judaica são subterfúgios do desejo de refúgio, o qual, ironicamente, só pode ser encontrado no outro. E este é indedutível em afeição, mas, também, o portador de um medo improrrogável: medo da fome, que o faz trabalhar; medo do ataque dos árabes, que o recruta para a batalha; medo do desterramento, que faz nascer raízes entre seus pés e o solo arenoso; medo da repetiçáa do holocausto, que define senso e sentido estéticos primorosos; medo de uma nova diáspora, que embrutece a expressão dos sentimentos por seus filhos; e, sobretudo, medo da solidão, medo de náo ter ouvintes.

Conhecer mais da vida nessa aldeia nos revela, em contraponto, a falácia da novidade dos dramas modernos relativos ao isolamento e à solidão nas metrópoles. Pois se há desejo íntimo, feiçóes psíquicas particulares e projetos para 
si, existem, ainda, independentemente da densidade demográfica, aflições que nos impedirão de conjugar ideais. Embora intensa e permanentemente conectadas, as bandas largas das metrópoles comprimem nossa alteridade, confinando-nos na aldeota de nossos princípios irrenováveis. Confirma-se para as metrópoles aquilo que Ioav Karni, secretário do kibutz, afirma sobre a pequena Ikhat: "a sociedade kibutziana não tem nenhuma resposta para a solidão. Mais do que isso: o próprio conceito de kibutz nega o conceito de solidão”.

Assim, é próprio a qualquer estrutura e dinâmica social a indiferença, a resistência e até mesmo a reação frente à carência fundante de nosso psiquismo. Em outras palavras, a economia das relaçóes indivíduo-sociedade explica-se, também, por uma teoria da escassez, sobre a qual o jovem Moshe, munido das contradiçóes próprias dos renitentes, pondera silenciosamente enquanto assiste a uma aula no curso secundário sobre a Revolução Francesa: "a maioria das pessoas necessita de mais afeto do que aquele que podem obter".

A perspectiva complexa que Amós Oz faculta ao leitor o leva a aproximaçóes com "A sociedade dos indivíduos", de Norbert Elias (1994), sob um aspecto fundamental. As relaçóes indivíduo-sociedade se desenvolvem de modo a produzirem, metodicamente, configuraçóes sobre as quais temos proeminência e controle, mas nos tornamos concretamente dependentes e ideologicamente reféns dessas relaçóes, sendo a individualidade apenas um estado de autoconsciência e a sociedade uma estrutura de relaçóes intangíveis para o indivíduo, apesar de os propósitos sociais nos arrastarem e de os nossos desejos mais íntimos serem dotados de uma intensidade diretamente proporcional à projeção social de sua amplitude. Em outras palavras, quanto mais forte a intensidade de nosso desejo, mais nós ficamos convictos de que esse mesmo desejo é (ou deve ser) verdadeiro coletivamente, o que justifica nossos fundamentalismos.

Transformamos desejos em vontades, vontades em sonhos e sonhos em utopias, na expectativa surda de que delas todos partilhem. "Ria, ria dos sonhos" é a canção entoada por Osnat, a qual nos é recomendada, enquanto se encarrega com acalanto da saúde de Martin Vanderberg, sapateiro e professor de esperanto, este em seus últimos dias de vida. A canção, cuja leveza do tema dispensa a ironia na pronúncia e no propósito, se torna o único remédio para alguém cuja austeridade dos ideais é obstruída por suas necessidades mais primárias e pelos medos mais infantis, visto que "apesar de Martin sustentar a 
ideia de que o desperdício é equivalente à exploração e a economia é um dever moral, [...] a escuridão o apavorava”.

$\mathrm{Na}$ ficção de Amós $\mathrm{Oz}$, não são possíveis os heróis. Há um combate entre derrotados, especialmente quando o combate é contra si mesmo, pois as fraquezas se igualam, os golpes desferidos consomem o que nos resta de energia ou nos abatem por completo. A memória das vitórias sucumbe ao ficcionismo do inconsciente, como se os calçados fabricados por Martin nos permitissem pisar com mais firmeza, mas sem que tocássemos efetivamente o chão.

Amós Oz é pródigo e prodigioso nas memórias e na ficção, como já nos demonstrou em "De Amor e Trevas" (2005). Nesta obra, recobre de honesto encantamento sua própria biografia de modo a rever as tragédias pessoais, subtraindo delas a dinâmica da vingança que compele a todos para uma espécie de compulsão à repetiçáo. Dessa maneira, em "Entre amigos" são possíveis as resistências ao modus operandi da insolência, da presunção, da vingança, da ganância e da competição, mas também são exigidas a aprendizagem e a comunhão da espera e do silêncio de Osnat, que elaborou seus lutos admitindo que "não sabia o que teria pra dizer".

Leitura morosa para tempos acelerados, indedutível e improrrogável, o livro "Entre amigos" contorna os dramas particulares e universais das relaçóes humanas na qualidade de um rio meândrico, cuja vagareza das águas umedece e fertiliza mais profundamente a terra indiferente à ferocidade daqueles que, necessariamente, dele dependem para saciar a sua sede; afinal, conforme afirma o silencioso jovem Iotam, "o homem é, basicamente, um animal distorcido".

Recebido em: 21.04.2014

Aprovado em: 10.11.2014

\section{Referências}

ELIAS, N. A sociedade dos indivíduos. Organizado por Michel Schröer; tradução de Vera Ribeiro; revisão técnica e notas de Renato Janine Ribeiro. 1. ed. Rio de Janeiro: Jorge Zahar Ed., 1994.

NERUDA, P. Poems. English \& Spanish. Selections. Edited and with a forework by Nathaniel 
Tarn; introduction by Alastair Reid; translated by Anthony Kenigan et al.. Bilingual ed. New York: Delacorte Press, 1972.

OZ, A. De amor e trevas. Tradução do hebraico e glossário de Milton Lando. São Paulo: Companhia das Letras, 2005.

Cenas da vida na aldeia. Tradução do hebraico e notas de Paulo Geiger. São Paulo: Companhia das Letras, 2008.

. Entre amigos. Tradução do hebraico e notas de Paulo Geiger. 1. ed. São Paulo: Companhia das Letras, 2014. 